PROFESI (Profesional Islam)

Media Publikasi Penelitian; 2017; Volume 15; No 1.

Website: ejournal.stikespku.ac.id

\title{
Asupan Kalium, Serat dan Tekanan Darah pada Pegawai Laki-Laki Bukan Perokok Bagian Produksi di PT. Dewa Prabu Surakarta
}

\author{
Laili Noor Anissa $^{1^{*}}$, Elida Soviana ${ }^{2}$ \\ ${ }^{1}$ Prodi Ilmu Gizi/Fakultas Ilmu Kesehatan, Universitas Muhammadiyah Surakarta \\ ${ }^{2}$ Prodi Ilmu Gizi/Fakultas Ilmu Kesehatan, Universitas Muhammadiyah Surakarta \\ *Email: Lailianissa046@gmail.com
}

\begin{abstract}
Kata Kunci
Asupan kalium, asupan serat, tekanan darah sistolik, tekanan darah diastolik.
\end{abstract}

\begin{abstract}
Abstrak
Seseorang yang mengalami masalah kesehatan akan dapat menurunkan tingkat produktivitas seperti adanya tekanan darah. Tekanan darah tinggi merupakan salah satu penyakit degeneratif yang sering dialami oleh orang dewasa. Salah satu faktor yang mempengaruhi tekanan darah yaitu asupan kalium dan serat. Kalium berpartisipasi dalam memelihara keseimbangan cairan, elektrolit, asam basa dan menurunkan tekanan darah. Asupan serat mengurangi kadar kolesterol yang bersikulasi dalam plasma darah, sehingga meningkatkan perubahan kolesterol plasma menjadi asam empedu. Penelitian ini bertujuan untuk mengetahui asupan kalium, serat dan tekanan darah pada pegawai laki-laki bukan perokok bagian produksi di PT. Dewa Prabu Surakarta. Jenis penelitian menggunakan observasional dengan pendekatan cross-ssectional. Data tekanan darah diperoleh dari pemeriksaan tekanan darah yang diukur menggunakan Sphygmomanometer, data asupan kalium dan serat diperoleh dari Food Frequency Quesioner (FFQ) semi quantitative. Penelitian ini menunjukkan bahwa rata-rata asupan kalium yaitu $2096.29 \mathrm{mg}$ dengan 100\% pegawai dalam kategori asupan kalium rendah, rata-rata asupan serat yaitu $20.66 \mathrm{~g}$ dengan 84,2\% pegawai dalam kategori asupan serat rendah, dan rata-rata tekanan darah yaitu pada tekanan darah sistolik $119.80 \mathrm{mmHg}$ dengan 52,6\% pegawai dalam kategori tekanan darah sistolik normal, sedangkan tekanan darah diastolik $80.40 \mathrm{mmHg}$ dengan 73,7\% pegawai dalam kategori tekanan darah diastolik dalam kategori normal.
\end{abstract}

\section{Potassium Intake, Dietary Fiber and Blood Pressure on Male Nonsmokers Employees Production Line in PT. Dewa Prabu Surakarta}

\section{Keywords}

Intake potassium, intake dietary fiber, blood pressure systolic, blood pressure diastolic.

\section{Abstract}

Someone who undergoes health problems such as the existence of blood pressure levels would significantly reduce of productivity. High blood pressure is one of the degenerative disease often experienced by adults. One factor affects blood pressure is potassium intake and dietary fibers. Potassium participates to take care of the equilibrium of fluids, an electrolyte, a base and acid lowering blood pressure. Intake of dietary fibers reduces cholesterol that circulate in the blood plasma, so as to increase the changes to existing formal cholesterol in the plasma into an acid bile. The purpose of this study is to know potassium intake, dietary fiber and blood pressure on men not smokers employees of production on un smoke men employees department in PT. Dewa Prabu Surakarta. The meth on of research usid observational by approach cross sectional. Data blood pressure obtained from the investigation the blood pressure as measured using sphygmomanometer, data intake potassium and dietary fiber obtained from food frequency questioner (FFQ). The research indicated that the average intake potassium consumed namely 2096,29 mg 
PROFESI (Profesional Islam)

Media Publikasi Penelitian; 2018; Volume 15; No 2.

Website: ejournal.stikespku.ac.id

with $100 \%$ employees in the category of low potassium intake, intake dietary fiber namely 20,66 $\mathrm{g}$ with 84,2\% employees in the category of dietary fiber intake low, and blood pressure namely blood pressure systolic $122.11 \mathrm{mmHg}$ with 52,6\% employees in the category of normal systolic blood pressure, while blood pressure diastolic $81.32 \mathrm{mmHg}$ with 73,7\% employees in the category of blood pressure diastolic in a category normal.

\section{PENDAHULUAN}

Konsumsi makanan yang kurang maupun berlebih akan menimbulkan dampak negatif bagi kesehatan. Konsumsi makanan adalah susunan makanan yang mencakup jenis dan jumlah bahan makanan rata-rata yang dikonsumsi individu perhari dalam jangka waktu tertentu (Baliwati et al., 2004). Salah satu faktor yang mempengaruhi konsumsi makanan adalah asupan makan. Asupan makan yang kurang maupun berlebih akan mempengaruhi tekanan darah. Pekerjaan yang dilakukan pegawai pabrik juga akan berdampak terhadap produktivitas. Pekerjaan yang dilakukan selama kurang lebih 8 jam perhari cenderung akan berdampak pada peningkatan maupun penurunan produktivitas.

Adanya target pencapaian produksi merupakan salah satu faktor yang mempengaruhi produktivitas. Berdasarkan survei pendahuluan yang dilakukan didapatkan bahwa target yang harus dicapai pegawai yaitu 775 pcs kain dalam 1 minggu. Terdapat sebanyak 15 lembar kain yang cacat dan tidak dapat dipasarkan karena adanya masalah kesehatan sehingga produksi tidak mencapai target. Beberapa tekanan yang mempengaruhi dalam memproduksi kain yaitu faktor cuaca, berhalangan hadir saat jam kerja hingga berdampak pada kain yang dihasilkan menjadi cacat dan tidak layak dipasarkan. Tuntutan tanggung jawab pekerjaan dapat mengakibatkan masalah kesehatan seperti peningkatan tekanan darah (Kodrat, 2011). Seseorang yang mengalami masalah kesehatan akan dapat menurunkan tingkat produktivitas seperti adanya tekanan darah tinggi. Adapun gejala tekanan darah tinggi antara lain sakit kepala/rasa berat di tengkuk, sakit kepala (vertigo), jantung berdebar-debar, mudah lelah, penglihatan kabur, telinga berdenging (tinnitus), dan mimisan (Depkes, 2014).

Tekanan darah merupakan tekanan yang dihasilkan oleh darah di pembuluh darah yang dipompa oleh jantung terhadap dinding arteri. Tekanan darah sebagai kekuatan pendorong bagi darah agar dapat beredar keseluruh tubuh untuk memberikan darah segar yang mengandung oksigen dan nutrisi ke organ-organ tubuh (Amiruddin et al., 2015). Efek jangka pendek tekanan darah tinggi akan menyebabkan peningkatan mortalitas, morbiditas dan penurunan produktivitas pada pegawai pabrik. Efek jangka panjang tekanan darah tinggi pada pegawai yaitu timbulnya kerusakan pada organ tubuh seperti terjadinya stroke hingga penyakit jantung koroner.

Tekanan darah tinggi merupakan salah satu penyakit degeneratif yang sering dialami oleh orang dewasa. Masalah ini cenderung meningkat di Indonesia. Prevalensi tekanan darah tinggi ditingkat nasional yang didapatkan dari pengukuran usia $\geq 18$ tahun pada tahun 2007 sebesar 31,7\% sedangkan pada tahun 2013 didapatkan hasil sebesar 25,8\%. Dari presentase tersebut didapatkan hasil bahwa terdapat penurunan presentase prevalensi tekanan darah tinggi sebesar 5,9\% pada tingkat nasional. Pada provinsi Jawa Tengah sendiri prevalensi tekanan darah tinggi didapatkan hasil sebesar 26,4\% (Riskesdas, 2013).

Tekanan darah tinggi merupakan faktor yang sangat penting pada sistem sirkulasi. Terjadinya tekanan darah tinggi disebabkan oleh beberapa faktor yang saling mempengaruhi. Banyak faktor yang dapat memperbesar risiko seseorang mengalami tekanan darah tinggi diantaranya umur, jenis kelamin, obesitas, stress, dan merokok. Faktor pendukung terjadinya tekanan darah tinggi yaitu asupan kalium yang rendah, asupan natrium yang tinggi serta kurangnya asupan serat (Anggara dan Prayitno, 2013).

Salah satu faktor yang mempengaruhi tekanan darah tinggi yaitu asupan kalium. Kalium erat hubungannya dengan penurunan tekanan darah. Kalium berpartisipasi dalam memelihara keseimbangan cairan, elektolit, dan asam basa. Kalium juga berperan dalam transmisi impuls saraf dan tekanan otot (Maria et al., 2012). 
PROFESI (Profesional Islam)

Media Publikasi Penelitian; 2018; Volume 15; No 2.

Website: ejournal.stikespku.ac.id

Asupan kalium dapat menurunkan tekanan darah sistolik dan diastolik. Konsumsi kalium lebih dari 2000mg/hari akan meningkatkan konsentrasi di dalam cairan intraselular, sehingga cenderung menarik cairan dalam ekstraselular dan menurunkan tekanan darah (Atun et al., 2014).

Berbeda dengan asupan kalium, konsumsi serat yang rendah juga mempengaruhi tekanan darah. Mekanisme serat dalam menurunkan tekanan darah yaitu serat dapat mencegah penyerapan kembali asam empedu, kolesterol dan lemak sehingga volume plasma menjadi berkurang (Puspitasari, 2009). Asam empedu mengemulsikan lemak hingga terurai menjadi asam lemak yang akan diserap tubuh. Jumlah asam empedu akan berkurang karena diikat oleh serat makanan. Kekurangan ini dapat diganti dengan membentuk asam empedu baru dari kolesterol yang ada di dalam darah. Konsentrasi kolesterol dalam darah akan menurun, sehingga dapat mengurangi terjadinya penyumbatan pembuluh darah jantung (Muchtadi, 2011). Dalam penelitian yang dilakukan tingkat asupan serat dipertahankan pada tingkat $\geq 25$ gram/hari (Fauziah et al., 2015). Sarifah et al., (2014) menyatakan bahwa terdapat hubungan antara asupan serat dengan kejadian hipertensi pada polisi di Polresta Pontianak dengan nilai $p$ sebesar 0,009 .

Berdasarkan survey pendahuluan yang dilakukan pada bulan Mei 2016 didapatkan hasil bahwa di Pabrik Tekstil Dewa Prabu terdapat $25 \%$ karyawan yang memiliki tekanan darah tinggi. Rata-rata asupan kalium yang dikonsumsi responden sebanyak $1735,19 \mathrm{mg} /$ hari, hal ini menunjukkan bahwa asupan kalium yang dikonsumsi responden kurang dari kebutuhan dengan sumber bahan makanan kalium yang sering dikonsumsi oleh pegawai pabrik yaitu bayam, pisang, dan kembang kol. Rata-rata asupan serat yang dikonsumsi responden sebanyak 197,46 gram/hari, hal ini menunjukkan bahwa asupan serat yang dikonsumsi responden kurang dari kebutuhan dengan sumber bahan makanan serat yang sering dikonsumsi oleh pegawai pabrik yaitu wortel, kacang panjang, buncis, kangkung dan jambu biji. Berdasarkan latar belakang diatas maka peneliti akan meneliti tentang "Asupan Kalium, Serat dan Tekanan Darah Pada Pegawai Laki-laki bukan Perokok Bagian Produksi di PT. Dewa Prabu Surakarta". Alasan pengambilan sampel penelitian di PT.
Dewa Prabu karena untuk mengetahui dan mendeskripsikan asupan kalium, asupan serat dan tekanan darah pada pegawai laki-laki bukan perokok bagian produksi.

\section{METODE PENELITIAN}

Penelitian ini dilaksanakan di PT. Dewa Prabu Surakarta. Penelitian ini dilaksanakan pada bulan Juli 2017. Penelitian ini menggunakan desan penelitian observasional dengan pendekatan cross sectional. Data tekanan darah diperoleh dari pemeriksaan tekanan darah yang diukur menggunakan Sphygmomanometer, data asupan kalium dan serat diperoleh dari Food Frequency Quesioner (FFQ) semi quantitative. Data hasil dari Food Frequency Quesioner (FFQ) semi quantitative yang diambil selama 1 bulan terakhir kemudian dihitung menggunakan nutrisurvey, sehingga didapatkan data asupan kalium dan serat dalam bentuk gram/hari, kemudian data diolah menggunakan SPSS 16.

\section{HASIL DAN PEMBAHASAN}

\subsection{Karakteristik Responden}

Responden dalam penelitian ini adalah pegawai Pabrik Tekstil Dewa Prabu yang berjumlah sebanyak 38 pegawai pabrik. Hal ini disebabkan karena laki-laki lebih banyak mengalami kemungkinan tekanan darah tinggi daripada perempuan, seringkali dipicu oleh beberapa faktor perilaku tidak sehat seperti merokok, konsumsi alkohol, perasaan kurang nyaman terhadap pekerjaan (Ahmad, 2011). Menurut Singalingging (2011) rata-rata perempuan akan mengalami peningkatan resiko tekanan darah tinggi setelah menopause yaitu usia diatas 45 tahun. Perempuan yang belum menopause dilindungi oleh hormone estrogen yang berperan dalam meningkatkan kadar High Density Lipoprotein (HDL). Kadar kolesterol HDL rendah dan tingginya kolesterol LDL (Low Density Lipoprotein) mempengaruhi terjadinya proses aterosklerosis (Anggraini et al., 2009). Aterosklerosis adalah pengerasan pembuluh darah yang disebabkan karena penyumbatan pada pembuluh darah. Penyumbatan dalam pembuluh darah menyebabkan tekanan darah menjadi tinggi (Nurahmi, 2006). Data karakteristik yang diambil meliputi pendidikan dapat dilihat pada Tabel 1 . 
PROFESI (Profesional Islam)

Media Publikasi Penelitian; 2018; Volume 15; No 2.

Website: ejournal.stikespku.ac.id

Tabel 1. Karakteristik Responden

\begin{tabular}{lcc}
\hline \multicolumn{1}{c}{ Pendidikan } & $\mathrm{n}$ & $(\%)$ \\
\hline Dasar & 19 & $50 \%$ \\
Lanjut & 19 & $50 \%$ \\
\hline
\end{tabular}

Berdasarkan distribusi tingkat pendidkan, responden dikategorikan menjadi tiga kategori yaitu pendidikan dasar dan pendidikan lanjut. Distribusi katakteristik responden berdasarkan pendidikan sebagian besar terdapat pada kategori tingkat lanjut sebesar 50\% dengan jumlah 19 responden. Pendidikan akan menentukan tingkat pendidikan seseorang, paling tidak kemampuan berpikir seseorang dengan pendidikan tinggi akan lebih luas. Tingkat pendidikan seseorang mempengaruhi kemampuan seseorang dalam menerima informasi yang diperoleh dan mengolahnya sebelum menjadi perilaku yang baik atau buruk sehingga dapat berpengaruh terhadap status kesehatannya (Notoatmodjo, 2003). Perilaku yang didasari oleh pengetahuan akan lebih mudah menerima informasi mengenai makanan yang baik.

\subsection{Distribusi Asupan Kalium, Serat dan Tekanan Darah}

Data asupan kalium dan asupan serat diperoleh dari wawancara langsung dengan responden menggunakan Food Frequency Quesioner (FFQ) Semi Kuantitatif selama 1 bulan terakhir. Data asupan kalium dan asupan serat didapat dari hasil perhitungan jumlah asupan yang dikonsumsi dalam satu hari dibandingkan dengan kebutuhan asupan sehari responden dan kemudian dikali 100. Data Tekanan darah tinggi diperoleh dari pemeriksaan tekanan darah yang diukur menggunakan Sphygmomanometer. Data tekanan darah dibedakan menjadi tekanan darah sistolik dan tekanan darah diastolik.

\subsubsection{Distribusi Responden Berdasarkan Asupan Kalium}

Tabel 2. Distribusi Responden berdasarkan Asupan Kalium

\begin{tabular}{lc}
\hline \multicolumn{1}{c}{ Statistik Deskriptif } & Asupan Kalium (mg) \\
\hline Mean & 2096.29 \\
Standar Deviasi & 594.413 \\
Nilai Minimum & 1157 \\
Nilai Maksimum & 3352 \\
\hline
\end{tabular}

Tabel 2 menunjukkan rata-rata asupan kalium responden sebesar 2096.29 mg. Berdasarkan nilai maksimum asupan kalium responden yaitu $3352 \mathrm{mg}$ yang berarti asupan kalium responden termasuk dalam kategori rendah karena berdasarkan AKG (2013) anjuran kebutuhan asupan kalium sebesar $4700 \mathrm{mg}$. Hal tersebut terjadi karena kurangnya mengkonsumsi makanan yang mengandung kalium. Kebiasaan makan yang kurang dapat menjadi faktor utama terjadinya defisit asupan kalium. Asupan kalium dapat membantu menurunkan tekanan darah seseorang (Jhondry, 2010).

Distribusi kategori asupan kalium dapat dilihat pada Tabel 3 .

Tabel 3. Distribusi Kategori Responden Berdasarkan Asupan Kalium

\begin{tabular}{lcc}
\hline Kategori Kalium & $\mathrm{n}$ & $\%$ \\
\hline Rendah & 38 & 100 \\
Normal & - & - \\
Total & 38 & 100 \\
\hline
\end{tabular}

Tabel 3 menunjukkan bahwa seluruh responden memiliki asupan kalium yang rendah. Asupan kalium seseorang dapat mempengaruhi tekanan darah seseorang. Kalium juga membantu mengaktivasi enzim (Winarno, 2004). Asupan kalium dengan tekanan darah dapat dipengaruhi oleh beberapa faktor selain asupan kalium. Hal tersebut dapat disebabkan karena faktor usia, kebiasaan berolahraga, stress, merokok dan riwayat keluarga. Asupan kalium yang meningkat akan menurunkan tekanan darah sistolik dan diastolik. Konsumsi tinggi kalium akan meningkatkan konsentrasinya didalam cairan intraseluler, sehingga cenderung menarik cairan dari bagian ekstraseluler dan menurunkan tekanan darah. Rasio kalium dan natrium berperan dalam mengendalikan tekanan darah (Astawan, 2005).

Hasil penelitian yang dilakukan oleh Mardanik dan Soviana (2012) menyatakan bahwa tidak ada hubungan antara asupan kalium dengan tekanan darah sistolik maupun tekanan darah diastolik. Hal tersebut disebabkan karena pengetahuan tentang asupan makan yang kurang terutama jenis pemilihan jenis makanan yang mengandung kalium. Hasil penelitian yang dilakukan oleh Syarifudin (2012) menyatakan bahwa tidak ada hubungan yang signifikan antara 
PROFESI (Profesional Islam)

Media Publikasi Penelitian; 2018; Volume 15; No 2.

Website: ejournal.stikespku.ac.id

asupan kalium dengan kejadian hipertensi pada polisi laki-laki di Kabupaten Purworejo dengan hasil penelitian menunjukkan nilai $\mathrm{p}$ sebesar 0,104 . Terdapat faktor lain yang dapat mempengaruhi tekanan darah seperti asupan lemak, asupan protein, status gizi dan kebiasaan merokok.

Berikut distribusi jenis bahan makanan berdasarkan sumber kalium yang dikonsumsi oleh responden dapat dilihat pada Tabel 4.

Tabel 4. Distribusi Jenis Bahan Makanan Berdasarkan Sumber Kalium

\begin{tabular}{lccccc}
\hline \multicolumn{1}{c}{ Sumber Kalium* } & Konsumen & $\%$ & $\begin{array}{c}\text { Konsumsi } \\
(\mathrm{g} / \text { hari })^{* *}\end{array}$ & Kalium $(\mathrm{g})$ & $\mathrm{n}$ \\
\hline Kecap & 33 & 90 & 9,63 & 5 & $2 \mathrm{x} / \mathrm{hr}$ \\
Pisang & 19 & 62 & 12,14 & 4,35 & $1 \mathrm{x} / \mathrm{bln}$ \\
Bayam & 31 & 86 & 17,39 & 4,16 & $2 \mathrm{x} / \mathrm{mgg}$ \\
Kentang & 13 & 50 & 4,52 & 3,96 & $1 \mathrm{x} / \mathrm{bln}$ \\
Santan & 37 & 98 & 10,92 & 3,24 & $1 \mathrm{x} / \mathrm{mgg}$ \\
Buncis & 21 & 66 & 8,90 & 2,95 & $1 \mathrm{x} / \mathrm{mgg}$ \\
Jagung & 23 & 70 & 13,39 & 2,60 & $1 \mathrm{x} / \mathrm{mgg}$ \\
Wortel & 34 & 92 & 15,57 & 2,45 & $3 \mathrm{x} / \mathrm{mgg}$ \\
Kol & 25 & 74 & 8,38 & 2,38 & $2 \mathrm{x} / \mathrm{mgg}$ \\
\hline
\end{tabular}

* Bahan makanan diurutkan berdasarkam jumlah kalium yang paling tinggi sesuai lampiran. Data selengkapnya dapat dilihat pada lampiran.

** Rata-rata konsumsi perhari berdasarkan jumlah pegawai pabrik yang mengkonsumsinya.

Pada Tabel 4 sumbangan kalium terbanyak diperoleh dari kecap. Rata-rata responden mengkonsumsi kecap sebanyak 9,63 $\mathrm{mg}$ /hari yang menghasilkan kalium sebesar $5 \mathrm{mg}$. Selain kecap, bahan makanan yang menyumbangkan kalium terbanyak yaitu pisang. Responden mengkonsumsi pisang sebanyak $12,14 \mathrm{mg} /$ hari yang menghasilkan kalium sebesar 4,35 mg sebanyak 1x/bulan.

Bahan makanan dengan tingkat konsumen paling tinggi yaitu santan. Selama seminggu responden mengkonsumsi santan dengan frekuensi 1x seminggu sebanyak 10,92 mg/hari dengan kandungan kalium sebanyak 3,24 g. Selanjutnya, konsumsi kalium tertinggi setelah santan yaitu wortel dengan frekuensi $3 \mathrm{x}$ seminggu sebanyak 15,57 $\mathrm{mg} /$ hari dengan kandungan kalium sebanyak 2,45 mg. Bahan makanan dengan tingkat konsumen paling rendah yaitu kentang dengan frekuensi konsumsi 1x/bulan sebanyak 4,52 $\mathrm{mg} /$ hari dengan kandungan kalium sebanyak 3,96 mg.

Peranan kalium hampir sama dengan natrium, yaitu kalium bersama-sama dengan natrium membantu menjaga tekanan osmotis dan keseimbangan asam basa. Kalium menjaga tekanan osmotik dalam cairan intraseluler (Fatmah, 2010). Peningkatan asupan kalium dapat menurunkan tekanan darah, penurunan tekanan darah ini dapat dikarenakan adanya penurunan resistensi vaskular akibat dilatasi pembuluh darah serta adanya peningkatan kehilangan air dan natrium dari tubuh hasil aktivitas pompa natrium dan kalium.

\subsubsection{Distribusi Responden Berdasarkan Asupan Serat}

Tabel 5. Distribusi Responden berdasarkan Asupan Serat

\begin{tabular}{ll}
\hline \multicolumn{1}{c}{ Statistik Deskriptif } & \multicolumn{1}{c}{ Asupan Serat $(\mathrm{g})$} \\
\hline Mean & 20.66 \\
Standar Deviasi & 7.56 \\
Nilai Minimum & 10.20 \\
Nilai Maksimum & 42.90 \\
\hline
\end{tabular}

Nilai rata-rata asupan serat responden sebesar 20.66 g. Berdasarkan nilai maksimum asupan serat responden yaitu $42.90 \mathrm{~g}$ yang berarti asupan serat responden termasuk dalam kategori tinggi karena berdasarkan AKG (2013) anjuran kebutuhan asupan serat sebesar $28 \mathrm{~g}$. Konsumsi makanan berserat tinggi memberikan efek hipoglikemik karena mampu memperlambat pengosongan lambung sehingga memberikan 
PROFESI (Profesional Islam)

Media Publikasi Penelitian; 2018; Volume 15; No 2.

Website: ejournal.stikespku.ac.id

efek rasa kenyang yang dapat menurunkan nafsu makan, mencegah kegemukan, dan mecegah penyakit degeneratif (Budiyanto, 2002).

Distribusi kategori asupan serat dapat dilihat pada Tabel 6.

Tabel 6. Distribusi Kategori Responden berdasarkan Asupan Serat

\begin{tabular}{lcc}
\hline \multicolumn{1}{c}{ Kategori Serat } & $\mathrm{n}$ & $\%$ \\
\hline Rendah & 32 & 84.2 \\
Normal & 6 & 15.8 \\
Total & 38 & 100 \\
\hline
\end{tabular}

Tabel 6 menunjukkan bahwa rata-rata responden memiliki asupan serat rendah sebesar $84,2 \%$ dari total responden. Konsumsi serat yang baik dapat menurunkan tekanan darah. Serat dapat mencegah penyerapan asam empedu sehingga darah akan menjadi lebih encer dan tekanan perifernya akan menjadi berkurang (Lairon, et. al., 2005). Asupan serat dengan tekanan darah dapat dipengaruhi oleh beberapa faktor seperti asupan makanan, kelebihan berat badan, merokok, faktor stress. Faktor makanan meliputi asupan protein, lemak jenuh dan natrium (Apriany dan Mulyati, 2012). Menurut Dauchet (2007) asupan serat mengurangi kadar kolesterol yang bersikulasi dalam plasma darah, karena serat dapat mencegah absorbsi kolesterol dalam usus, dan meningkatkan ekskresi asam empedu ke feses, sehingga meningkatkan perubahan kolesterol plasma menjadi asam empedu. Mengkonsumsi serat sangat menguntungkan karena dapat mengurangi pemasukan energi yang pada akhirnya menurunkan risiko penyakit tekanan darah tinggi (Baliwati et al., 2004).

Hasil penelitian yang dilakukan oleh Sangadji (2013) menyatakan bahwa konsumsi serat kurang sebesar $74,6 \%$ dengan prevalesi kejadian hipertensi sebesar $68,1 \%$ terdapat pada pramudi bus transjakarta di PT. Bianglala Metropolitan tahun 2013. Pada pekerja di Spanyol dilakukan penelitian the Argon Workers Health Study (AWHS) yang termasuk dalam studi Kohort, diketahui bahwa dari asupan serat yang dievaluasi didapatkan hasil yaitu rata-rata asupan serat yang dikonsumsi adalah $25,7 \mathrm{~g}$ /hari. sumber makanan yang paling sering dikonsumsi pada serat tidak larut air yaitu buah, sereal gandum, roti gandum dan kacang-kacangan, sedangkan pada serat tidak larut air yaitu buah-buahan dan kacang-kacangan (Franco et al., 2014).

Berikut distribusi jenis bahan makanan berdasarkan sumber serat yang dikonsumsi oleh responden dapat dilihat pada Tabel 7 .

Tabel 7. Distribusi Jenis Bahan Makanan Berdasarkan Sumber Serat

\begin{tabular}{lccccc}
\hline \multicolumn{1}{c}{ Sumber Serat* } & Konsumen & $\%$ & $\begin{array}{c}\text { Konsumsi } \\
(\mathrm{g} / \mathrm{hari})^{* *}\end{array}$ & $\begin{array}{c}\text { Serat } \\
(\mathrm{g})\end{array}$ & $\mathrm{n}$ \\
\hline Jambu Biji & 23 & 70 & 5,23 & 5,6 & $1 \mathrm{x} / \mathrm{mgg}$ \\
K. Hijau & 17 & 58 & 2,84 & 4,3 & $1 \mathrm{x} / \mathrm{mgg}$ \\
Wortel & 34 & 92 & 14,56 & 3,3 & $3 \mathrm{x} / \mathrm{mgg}$ \\
K. Pnjang & 27 & 78 & 10,70 & 3,2 & $3 \mathrm{x} / \mathrm{mgg}$ \\
Buncis & 21 & 66 & 8,33 & 3,2 & $1 \mathrm{x} / \mathrm{mgg}$ \\
Kangkung & 30 & 84 & 8,35 & 3,1 & $1 \mathrm{x} / \mathrm{mgg}$ \\
Brokoli & 13 & 50 & 11,06 & 2,9 & $1 \mathrm{x} / \mathrm{mgg}$ \\
Jeruk & 31 & 86 & 8,16 & 2,0 & $1 \mathrm{x} / \mathrm{mgg}$ \\
Anggur & 8 & 40 & 3,10 & 1,7 & $1 \mathrm{x} / \mathrm{bln}$ \\
Tempe & 38 & 100 & 58,35 & 1,4 & $2 \mathrm{x} / \mathrm{hari}$ \\
*Bahan makanan diurutkan berdasarkam jumlah kalium & yang paling & tinggi sesuai lampiran. Data \\
$\quad$ selengkapnya dapat dilihat pada lampiran. & \multicolumn{4}{c}{} \\
** Rata-rata konsumsi perhari berdasarkan jumlah pegawai pabrik yang mengkonsumsinya.
\end{tabular}

Pada Tabel 7 sumbangan serat terbanyak diperoleh dari jambu biji. Rata-rata responden mengkonsumsi jambu biji sebanyak 5,23 g/hari yang menghasilkan serat sebesar 5,6 g. Selain jambu biji, bahan makanan yang menyumbangkan serat terbanyak yaitu kacang hijau. Responden mengkonsumsi kacang hijau sebanyak 2,84 
PROFESI (Profesional Islam)

Media Publikasi Penelitian; 2018; Volume 15; No 2.

Website: ejournal.stikespku.ac.id

$\mathrm{g} /$ hari yang menghasilkan serat sebesar 4,3 $\mathrm{g}$ sebanyak 1x/minggu.

Bahan makanan dengan tingkat konsumen paling tinggi yaitu tempe. Setiap hari responden mengkonsumsi tempe dengan frekuensi $2 \mathrm{x}$ sehari sebanyak 58,35 g/hari dengan kandungan serat sebanyak 1,4 g. Selanjutnya, konsumsi kalium tertinggi setelah tempe yaitu wortel dengan frekuensi $3 \mathrm{x}$ seminggu sebanyak 14,56 $\mathrm{g}$ /hari dengan kandungan serat sebanyak 3,3 g. Bahan makanan dengan tingkat konsumen paling rendah yaitu anggur dengan frekuensi konsumsi $1 \mathrm{x} /$ bulan sebanyak 3,10 g/hari dengan kandungan serat sebesar $1,7 \mathrm{~g}$.

Serat merupakan bagian dari tumbuhan yang dapat dikonsumsi dan tersusun dari karbohidrat yang memiliki sifat resistan terhadap proses pencernaan dan penyerapan di usus halus manusia serta mengalami fermentasi sebagian atau keseluruhan di usus besar. Sumber bahan makanan kaya serat sangat mudah ditemukan pada sayur-sayuran dan buah-buahan. Serat memiliki fungsi untuk mengontrol berat badan, penanggulangan penyakit diabetes, mencegah gangguan gastrointestinal, serta mengurangi tingkat kolesterol darah, penyakit degeneratif dan kardiovaskuler (Santoso, 2011).

\subsubsection{Distribusi Responden Berdasarkan Tekanan Darah}

Tabel 8. Distribusi Responden Berdasarkan Tekanan Darah

\begin{tabular}{lll}
\hline \multicolumn{1}{c}{$\begin{array}{c}\text { Statistik } \\
\text { Deskriptif }\end{array}$} & \multicolumn{1}{c}{$\begin{array}{c}\text { Sistolik } \\
(\mathrm{mmHg})\end{array}$} & \multicolumn{1}{c}{$\begin{array}{c}\text { Diastolik } \\
(\mathrm{mmHg})\end{array}$} \\
\hline Mean & 122.11 & 81.32 \\
Standar Deviasi & 11.42 & 6.22 \\
Nilai Minimum & 100 & 70 \\
Nilai Maksimum & 140 & 90 \\
\hline
\end{tabular}

Nilai rata-rata tekanan darah responden yaitu tekanan darah sistolik $122.11 \mathrm{mmHg}$ dan tekanan darah diastolik $81.32 \mathrm{mmHg}$. Nilai maksimum tekanan darah responden yaitu sebesar 140/90 $\mathrm{mmHg}$ termasuk dalam kategori tinggi. Berdasarkan JNC VII tekanan darah normal seseorang yaitu 120/80 mmHg. Tekanan darah sistolik ialah tekanan darah pada saat jantung memompa darah ke dalam pembuluh nadi, sedangkan tekanan darah diastolik adalah tekanan darah pada saat jantung mengembang dan memompa darah kembali (jantung beristirahat) (Bangun, 2002).

Distribusi kategori tekanan darah sistolik dan diastolik dapat dilihat pada Tabel 9.

Tabel 9. Distribusi Kategori Responden Berdasarkan Tekanan Darah

\begin{tabular}{lcccc}
\hline Kategori Tekanan & \multicolumn{2}{c}{ Sistolik } & \multicolumn{2}{c}{ Diastolik } \\
\cline { 2 - 5 } \multicolumn{1}{c}{ Darah } & $\mathrm{n}$ & $\%$ & $\mathrm{n}$ & $\%$ \\
\hline Normal & 20 & 52.6 & 28 & 73.7 \\
Tinggi & 18 & 47.4 & 10 & 26.3 \\
Total & 38 & 100 & 38 & 100 \\
\hline
\end{tabular}

Pada Tabel 9 menunjukkan bahwa 52,6\% dari total responden memiliki tekanan darah sistolik dalam kategori normal, sedangkan pada tekanan darah sistolik menunjukkan bahwa $73,7 \%$ responden memiliki tekanan darah dalam kategori normal. Tekanan darah merupakan gaya yang diberikan darah terhadap dinding pembuluh darah dan ditimbulkan oleh desakan darah terhadap dinding arteri ketika darah dipompa dari jantung ke jaringan. Tekanan darah sistolik berkaitan dengan tingginya tekanan pada arteri bila jantung berkontraksi, sedangkan tekanan darah diastolik merupakan tekanan yang dihasilkan pada saat jantung berelaksasi setelah berdenyut (Sani, 2008). Peningkatan atau penurunan tekanan darah akan mempengaruhi homoestasis di dalam tubuh. Tekanan darah diperlukan untuk mengalirnya darah di dalam arteri, arteriola, kapiler dan sistem vena, sehingga terbentuklah suatu aliran darah yang menetap (Aris, 2007).

\section{KESIMPULAN}

Kesimpulan dari penelitian ini rata-rata asupan kalium yaitu $2096.29 \mathrm{mg}$ dengan 100\% pegawai dalam kategori asupan kalium rendah, rata-rata asupan serat yaitu $20.66 \mathrm{~g}$ dengan $84,2 \%$ pegawai dalam kategori asupan serat rendah, dan rata-rata tekanan darah yaitu pada tekanan darah sistolik $119.80 \mathrm{mmHg}$ dengan $52,6 \%$ pegawai dalam kategori tekanan darah sistolik normal, sedangkan tekanan darah diastolik $80.40 \mathrm{mmHg}$ dengan $73,7 \%$ pegawai dalam kategori tekanan darah diastolik dalam kategori normal. 


\section{REFERENSI}

Amiruddin, M. A., Danes, V. R., dan Lintong, F. 2015. Analisa Hasil Pengukuran Tekanan Darah Antara Posisi Duduk Dan Posisi Berdiri Pada Mahasiswa Semester VII (Tujuh) TA. 2014/2015 Fakultas kedokteran Universitas SAM RATULANGI. Jurnal E-Biomedik (eBm), 3(April), 125-129.

Anggara, D. H. F., dan Prayitno, N. 2013. FaktorFaktor Yang Berhubungan Dengan Tekanan Darah di Puskesmas Telaga Murni Cikarang Barat Tahun 2012. Jurnal Ilmiah Kesehatan, volume 5(1), $20-25$.

Anggraini, A. D., Ked, S., Waren, A., Situmorang, E., Asputra, H., dan Siahaan, S. S. 2009. Faktor-Faktor Yang Berhubungan Dengan Kejadian Hipertensi Pada PAsien Yang Berobat Di Poliklinik Dewasa Puskesmas Bangkinang Periode Januari Sampai Juni 2008 Authors: Medicine, 0-41.

Angka Kecukupan Gizi (AKG). 2013. Tabel Angka Kecukupan Gizi 2013 bagi Orang Indonesia

Apriany, R. E. A., Mulyati, T. 2012. Asupan Protein, Lemak Jenuh, Natrium Serat dan IMT Terkait dengan Tekanan Darah Pasien Hipertensi di RSUD Tugurejo Semarang. Artikel Penelitian. Universitas Diponegoro. Semarang

Atun, L., Siswati, T., dan Kurdanti, W. 2014. Sources of Sodium Intake , Sodium Potassium Ratio, Physical Activity, and Blood Pressure of Hypertention Patients Dinas Kesehatan Kabupaten Sleman ta-. MGMI, 6(No. 1), 63-71.

Baliwati, Y. F., Khomsan, A., dan Dwiriani, C. M. 2004. Pengantar Pangan dan Gizi. Jakarta: Penebar Swadaya.

Dauchet, L. 2007. Dietary Patterns and Blood Pressure Change Over 5-y follow-up in the SU. VI MAX Cohort. Am j Clin Nuth 85: $1650-6$
Fatmah. 2010. Gizi Usia Lanjut. Jakarta: Erlangga

Fauziah, N. Y., Bintanah, S., dan Kusuma, H. S. 2015. Hubungan Asupan Bahan Makanan Sumber Serat, Asupan Natrium, Asupan Lemak dan IMT dengan Tekanan Darah pada Pasien Hipertensi Rawat Jalan di Rumah Sakit Tugurejo Semarang. Jurnal Gizi, 4(1), 8-12.

Franco, Belen Moreno, Montserrat Leon Latre, Eva Maria Andres Esteban, Jose Maria Ordovas, Jose Antonio Casasnovas and Jose Luis penalvo. 2014. Soluble and Insoluble Dietary Dibre Intake and Risk Factors For Metabolic Syndrome and Cardiovascular Disease in Middle-Aged Adults: the AWHS Cohort. Nutrition Hospitalaria. Nutr Hosp. 2014; 30(6): 1279-1288.

Jhondry. 2010. Perilaku Penderita Hipertensi terhadap Upaya Pencegahan Komplikasi di Wilayah Kerja Puskesmas Berastagi tahun 2010. Universitas Sumatra Utara.

Kodrat, K. F. 2011. Pengaruh Shift Kerja Terhadap Kelelahan Pekerja Pabrik Kelapa Sawit di PT. X Labuhan Batu. Jurnal Teknik Industri, 12, 110-117.

Lairon D, Arnault N, Betrais S, Planells R, Clero E., Hechberg S, et al., Dietary Fiber Intake and Risk Factors for Cardiovascular Disease in French adults. Am J Clin Nutr (serial online) 2005; 82: 1185-94

Mardanik, Tri dan Soviana, Elida, S.Gz., M.Gizi. 2017. Hubungan Asupan Natrium dan Kalium Terhadap Tekanan Darah Pada Pegawai Negeri Sipil (PNS) Dinas Kesehatan Kota Surakarta. Skripsi Thesis. Universitas Muhammadiyah Surakarta. Surakarta

Maria, G., Puspita, R. D., dan Sulistyowati, Y. 2012. Hubungan Asupan Natrium dan Kalium Dengan Tekanan Darah Pada Pasien Hipertensi Di Unit Dili Timor Leste Intake (With Blood Pressure on Hypertension Patients At the Outpatient Unit in Dili ' $S$ Guido). Respati Yogyakarta. 
PROFESI (Profesional Islam) Media Publikasi Penelitian; 2018; Volume 15; No 2.

Website: ejournal.stikespku.ac.id

Notoatmodjo, D. S. 2003. Ilmu Kesehatan Masyarakat. Jakarta: PT Rineka Cipta.

Nurahmi., Aprianti, S., Arif, M., Hardjoeno. 2006. Nilai Small Dense LDL dan Kaitannya dengan Lipid Lainnya. Indonesian Journal of Clinical Pathology and Medical Laboratory. 15 (1): 17 - 19

Riskesdas. 2013. Riset Kesehatan Dasar 2013. Riset Kesahatan Dasar, 111-116.

Sani, A. 2008. Hypertension; Current Perspective. Medya Crea. Jakarta

Santoso, I. A. M. 2011. Serat pangan (Dietary Fiber) dan Manfaatnya Bagi Kesehatan, (75), 35-40.
Sarifah, Sally Mustika, Indah Budiastutik dan Andri Dwi Hernawan. 2014. Hubungan Antara Asupan Zat Gizi, Aktifitas Fisik dan Gaya Hidup dengan Kejadian Hipertensi pada Polisi di Polresta Pontianak. Jurnal Mahasiswa dan Penelitian Kesehatan. Universitas Muhammadiyah Pontianak.

Singalingging, G. 2011. Karakteristik Penderita Hipertensi di Rumah Sakit Umum Herna Medan 2011. Medan: 1-6

Syarifudin, A. 2012. Hubungan antara Faktor Sosiodemografik dan Gaya Hidup dengan Kejadian Hipertensi pada Polisi Laki-laki di Kabupaten Purworejo, Jawa Tengah. Skripsi. Universitas Indonesia

Winarno, F. G. 2004. Kimia Pangan dan Gizi. Jakarta: Gramedia Pustaka Utama. 